\title{
Obesity-Associated Inflammation: Does Curcumin Exert a Beneficial Role?
}

\author{
Rosaria Varì, Beatrice Scazzocchio (D), Annalisa Silenzi, Claudio Giovannini and Roberta Masella *(D) \\ Center for Gender-Specific Medicine, Gender Specific Prevention and Health Unit, Istituto Superiore di Sanità, \\ Viale Regina Elena 299, 00161 Rome, Italy; rosaria.vari@iss.it (R.V.); beatrice.scazzocchio@iss.it (B.S.); \\ annalisa.silenzi@iss.it (A.S.); claudio.giovannini@iss.it (C.G.) \\ * Correspondence: roberta.masella@iss.it
}

Citation: Varì, R.; Scazzocchio, B.; Silenzi, A.; Giovannini, C.; Masella, R. Obesity-Associated Inflammation: Does Curcumin Exert a Beneficial Role? Nutrients 2021, 13, 1021. https://doi.org/10.3390/nu13031021

Academic Editor: Giuseppe Grosso

Received: 25 February 2021

Accepted: 18 March 2021

Published: 22 March 2021

Publisher's Note: MDPI stays neutral with regard to jurisdictional claims in published maps and institutional affiliations.

Copyright: (c) 2021 by the authors. Licensee MDPI, Basel, Switzerland. This article is an open access article distributed under the terms and conditions of the Creative Commons Attribution (CC BY) license (https:// creativecommons.org/licenses/by/ $4.0 /)$.

\begin{abstract}
Curcumin is a lipophilic polyphenol, isolated from the plant turmeric of Curcuma longa. Curcuma longa has always been used in traditional medicine in Asian countries because it is believed to have numerous health benefits. Nowadays it is widely used as spice component and in emerging nutraceutical food worldwide. Numerous studies have shown that curcumin possesses, among others, potential anti-inflammatory properties. Obesity represents a main risk factor for several chronic diseases, including type 2 diabetes, cardiovascular disease, and some types of cancer. The establishment of a low-grade chronic inflammation, both systemically and locally in adipose tissue, occurring in obesity most likely represents a main factor in the pathogenesis of chronic diseases. The molecular mechanisms responsible for the onset of the obesity-associated inflammation are different from those involved in the classic inflammatory response caused by infections and involves different signaling pathways. The inflammatory process in obese people is triggered by an inadequate intake of nutrients that produces quantitative and qualitative alterations of adipose tissue lipid content, as well as of various molecules that act as endogenous ligands to activate immune cells. In particular, dysfunctional adipocytes secrete inflammatory cytokines and chemokines, the adipocytokines, able to recruit immune cells into adipose tissue, amplifying the inflammatory response also at systemic level. This review summarizes the most recent studies focused at elucidating the molecular targets of curcumin activity responsible for its anti-inflammatory properties in obesity-associated inflammation and related pathologies.
\end{abstract}

Keywords: curcumin; obesity; inflammation; adipose tissue

\section{Introduction}

Curcumin, the main natural polyphenol found in the rhizome of Curcuma longa (turmeric) [1], has been recognized for thousands of years because of its medicinal properties and potential health benefits [2]. It is used worldwide in different forms: as spice, antiseptic, anti-inflammatory, preservative or coloring agent, as well as supplement in capsules or powder form [3]. It has been reported the beneficial effect of curcumin in various diseases, including inflammatory and degenerative conditions, cancer, dyslipidemia, metabolic syndrome (MetS), and obesity [4-7]. Several studies have also shown that most of the benefits are due to its antioxidant and anti-inflammatory activities [5]. Overweight and obesity are a major public health problem all over the world [8]. Obesity is caused by the imbalance between energy intake and energy expenditure, culminating in the excess of fat accumulation in the adipose tissue (AT) [9]. It is associated with a chronic low-grade inflammation that might represent the main factor linking obesity and the development and progression of various diseases including type 2 diabetes (T2D), dyslipidemia, heart diseases, stroke, and cancer $[10,11]$. AT, indeed, is recognized as an endocrine organ that secretes a number of cytokines and chemokines with regulatory and immune functions [12]. Dysfunctions of the secretory activity of AT, thus, most likely play a pathogenic role in the occurrence of the obesity-related pathologies [13]. In consideration of this, the current 
review examines specifically the possible role of curcumin in counteracting the activation of inflammatory pathways in AT. To this purpose, we conducted a comprehensive literature search until December 2020 in PubMed, using "obesity", "inflammation", "adipose tissue", "adipocyte" as key words in combination with "curcumin" and "dietary curcumin".

\section{Obesity, AT Dysfunction and Inflammation}

Obesity is characterized by an excessive AT expansion due to hyperplasia (increase in number) and / or hypertrophy (increase in size) of adipocytes, the major cellular component of AT. Although the main function of adipocytes is the storage and release of lipids, they secrete also active molecules that are used for intracellular signaling and to communicate with every organ system in the body. The second largest AT cellular component beyond adipocytes are resident immune cells that, in turn, play important roles in the maintenance of AT homeostasis. The intensity and complexity of these signal networks are highly regulated, differ in each fat pad, and are dramatically affected by various disease states. In conclusion, $\mathrm{AT}$ is an active endocrine organ, secreting a variety of hormones and metabolites that regulate systemic metabolism. When the imbalance in the storage of lipids by fat cells is established, alterations in secretive function occur and systemic metabolic dysfunctions might happen, such as in T2D, cardiovascular and liver diseases, and cancers. Through these cellular derangement and metabolic dysfunction, an excessive caloric intake contributes to a chronic low-grade inflammation, also known as 'metainflammation'. In particular, visceral AT accumulated in the abdominal seat, shows a disrupted balance between secreted pro- and anti-inflammatory factors, with increased levels of pro-inflammatory adipocytokines, including leptin [14], and decrease of anti-inflammatory adipokines, such as adiponectin [15]. These events all together cause local alterations of the AT environment and alter the normal cross-talk with other organs, such as liver, muscle, brain, and pancreas $[16,17]$, which leads, as a further result, to metabolic dysfunctions, such as hyperinsulinemia and insulin resistance (IR) [11]. Furthermore, the polarization profile of the resident immune cells depends on the health status of the adipocytes [18]. Changes in the adipocyte secretion profile, in fact, trigger the recruitment and activation of immune cells [19]. In particular, in obese subjects, AT macrophages shift from an anti-inflammatory profile (such as that found in normal weight people) towards a pro-inflammatory phenotype $[20,21]$ producing themselves an alteration in the production/activation of key factors that exacerbate local and systemic inflammation [22], such as tumor necrosis factor (TNF) $\alpha$, interleukin (IL)-6, IL-1 $\beta$, toll-like receptor (TLR) 4 , and nuclear factor (NF)- $\mathrm{kB}$, that may amplify the inflammatory state and favor the onset of pathologies [23-27]. The pro-inflammatory profile in obese individuals is evidenced by elevated serum levels of TNF $\alpha$ and IL-6, simultaneously with adiponectin and anti-inflammatory cytokines decrease $[28,29]$. The expression of the proinflammatory cytokines is regulated by the activation of the transcription factor NF- $\mathrm{kB}$. This factor is stored in the cytoplasm as inactive form bound to the inhibitor IкB $\alpha$ that is, in turn, regulated by the inhibitor of $\mathrm{KB}$ kinase (IKK) complex consisting of 2 subunits, IKK $\alpha$ and IKK $\beta$. Different stimuli, including growth factors, cytokines and foreign pathogens or molecules, such as lipopolysaccharides (LPS) and free fatty acids (FFA) [30], activate the IKK kinase complex inducing proteasomal degradation of IKB $\alpha$ and leading to the translocation of NF- $\mathrm{KB}$ in the nucleus, where it induces the expression of genes of various inflammatory mediators. Obese people show an increased activation of NF- $\mathrm{kB}$ pathway, most likely responsible for the increased pro-inflammatory cytokine release [31]. Among the pro-inflammatory compounds, it should be mentioned leptin; it is primarily produced by AT, its level increases in obese people and participates in the control of body weight by regulating food intake and energy expenditure [32]. On the other hand, adiponectin, produced almost exclusively by AT, circulates in high concentration in plasma and has anti-inflammatory properties probably related to the inhibition of NF- $\mathrm{KB}$ activation and, consequently, to the reduced synthesis of pro-inflammatory cytokine [33,34]. The secretion of anti-inflammatory adipocytokines is inhibited in visceral AT from obese patients and 
subjects with MetS leading to a significant reduction in their plasma levels [35,36]. Despite the intense experimental work carried out, the exact molecular mechanisms responsible for the chronic low-grade metabolic inflammation in obesity are not completely clarified yet. However, with the identification of the nod-like receptor pyrin domain-containing (NLRP) 3 inflammasome in AT, a new hypothesis has been formulated suggesting that it might be relevant for regulating obesity-associated inflammation and insulin sensitivity [37]. The NLRP3 inflammasome is a cytosolic molecular complex whose expression in AT directly correlates with body weight and aging, while its inactivation significantly mitigates metabolic disorders [38,39]. A number of exogenous and endogenous signals might act as NLRP3 inflammasome activator in AT leading to the production of pro-inflammatory cytokines [40,41] a potential mechanism linking an elevated intake of saturated fatty acids (SFAs) to the progression of metabolic diseases. In line with this, increased gene expressions of NLRP3 and its key effectors IL-1 $\beta$ and IL-18 have been observed in visceral fat of metabolically unhealthy individuals compared to those from lean healthy control or metabolically healthy obese individuals [42]. Furthermore, these inflammatory effects were suppressed, after weight loss, in the subcutaneous fat of patients with obesity and T2D, with consequent improvement in insulin sensitivity [38]. Studies have hypothesized a causal nexus between systemic inflammation and an increased release of FFA from AT in obese and insulin-resistant subjects $[43,44]$. Indeed, the direct drainage of free FA and adipokines from visceral AT to the liver can activate immune responses leading to the secretion of inflammatory compounds [17]. A potential mechanism of action through which FFA, and mainly dietary SFAs, can mediate AT dysfunctions contributing to the onset of inflammation involves the TLR4 [45,46]. TLR4 belongs to the TLR family and is expressed not only on leukocytes but also on many non-immune cells, including adipocytes, hepatocytes, and muscle cells. It has been hypothesized that FFA can bind and stimulate TLR4; thus, the elevated plasma level of FFA observed in obesity could activate TLR4. A recent research showed that the TLR4 activation can mediate inflammatory processes also through the impairment of adipogenesis which, in turn, elicit adipocyte and resident immune cell dysfunctions [47]. In conclusion, the onset of inflammatory processes linked to obesity and metabolic dysfunction in AT involves a number of different factors closely intertwined. The inflammation associated with obesity has been shown to derive from changes in the delicate crosstalk between adipocytes and macrophages due to an increased infiltration of macrophages into AT, the activation of a number of pro-inflammatory pathways, the alterations of adipokine production and increased expression and release of a panel of inflammatory cytokines. Understanding the molecular and metabolic switches that, starting from AT, lead to immune cells polarization towards inflammatory phenotypes may allow the definition of interventions capable of leading to the resolution of inflammation and blocking the sequence of events responsible for the occurrence of clinical complications in obesity. Targeting the key intracellular pathways underlying AT dysfunctions might represent a useful tool in counteracting obesity-related pathologies. From this point of view, the identification of potential protective activity of curcumin in positively modulating AT pro/anti-inflammatory balance has been gaining significant interest.

\section{Curcumin and Inflammation in Obesity}

Several studies carried out in humans have shown that curcumin attenuates inflammation in obesity and obesity-related diseases by rebalancing the equilibrium between antiand pro-inflammatory factors via different mechanisms due to the interactions of curcumin with a wide range of biomolecules, such as transcription factors, cellular receptors, growth factors, enzymes, cytokines, and chemokines [48,49]. Moreover, some reports have suggested that curcumin can enhance weight loss induced by diet and lifestyle intervention on overweight subjects with MetS $([50,51]$. However, it should be considered that a main problem in the use of curcumin is its poor bioavailability. To increase curcumin bioavailability, different delivery systems including micelles, liposomes, phospholipid complexes, nanostructured lipid carriers, and biopolymer nanoparticles have been developed, as well 
as the addition of piperine, a bioactive alkaloid extracted from the Piper species, which has been shown to effectively enhance the bioavailability of several nutritional supplements including curcumin [52].

\section{Curcumin Decreases Circulating Inflammatory Markers in Overweight/Obese Subjects}

There is an increasing evidence that curcumin treatment could be able to alleviate the altered pro-inflammatory mediator secretions present in obesity and related pathologies. In this section, data from human studies carried out on overweight and obese subjects with curcumin supplementation are collected and summarized. A research performed on 84 overweight or obese patients with non-alcoholic fatty liver disease (NAFLD) demonstrated that, curcumin supplementation with two $40 \mathrm{mg}$ capsules/day after meals for 3 months, induces a decrease in many serum inflammatory markers, such as TNF $\alpha$, high-sensitive C-reactive protein (hs-CRP), and IL-6 [53]. The same conclusions were reached by other studies carried out in obese/overweight people; specifically, curcumin administration $(1 \mathrm{~g} /$ day) for 8 weeks reduces serum concentrations of TNF $\alpha$, IL- 6 , and monocyte chemoattractant protein 1 (MCP-1) in males and females with diagnosis of MetS with respect to the placebo group [7]. In a randomized placebo-controlled clinical trial carried out on 60 adolescent girls undergoing to a slight weight-loss diet for 10 weeks, curcumin consumption ( $500 \mathrm{mg} /$ day) was able to induce a significant decrease in hs-CRP and IL-6 compared to placebo supplementation [54]. In addition, it has been demonstrated that curcumin modulates circulating levels of IL-1 $\beta$ in thirty subjects randomized to receive curcumin $(1 \mathrm{~g} /$ day $)$ or a matched placebo for 4 weeks. Serum IL- $1 \beta$ was found to be significantly reduced by curcumin treatment. In contrast, no significant difference was observed in the concentrations of IL-6, and MCP-1 [55]. Finally, curcuminoids supplementation ( $300 \mathrm{mg}$ /day) for 3 months in T2D patients led to a significant decrease in circulating FFA levels [56], that are considered a major factor linking obesity and inflammation [57-59].

\section{Curcumin Modulates Adipokines}

Adiponectin and leptin are two important adipokines released by adipocytes that have [18] several target organs including brain, liver, pancreas, muscle, immune system, and AT itself. They are involved in inflammation and immune response, showing, as stated above, adiponectin anti-inflammatory properties, leptin, on the contrary, pro-inflammatory ones [60]. Obese subjects are characterized by an imbalance of the two adipokines showing a low concentration of adiponectin and high levels of leptin in plasma [61]. Curcumin has been shown to increase the production of adiponectin [62]. To this regard, a systematic review [63] showed that curcuminoid administration significantly increased plasma adiponectin concentrations in randomized controlled trials. Specifically, in a double-blind randomized trial carried out over a 12-week period on 118 patients with T2D the effects of the daily administration of $1 \mathrm{~g}$ curcumin added with $10 \mathrm{mg}$ piperine were compared to placebo. The treatment with curcumin plus piperine reduced serum levels of TNF $\alpha$ and increased serum level of adiponectin [64]. In another study, curcumin supplementation $(1 \mathrm{~g} /$ day) for 6 weeks increased serum adiponectin concentrations compared to both curcumin-phospholipid complex ( $1 \mathrm{~g} /$ day) and placebo groups in 120 men and women with MetS [65]. In a randomized double-blind study 44 men and women with T2D were treated with curcumin $1500 \mathrm{mg} /$ day or placebo for 10 weeks. At the end of the study, a significant increase in serum adiponectin concentration together with a decrease in the mean weight were observed in the curcumin group [66]. Conversely, no effect on adiponectin was seen in 22 young men randomly assigned to receive curcumin (500 $\mathrm{mg}$ /day) or placebo for 12 weeks. This finding might be determined by the low dose of curcumin used for the treatment [67]. However, the same amount of curcumin (500 mg/day) for 4 weeks reduced serum leptin and resistin and increased adiponectin content in 15 children and 15 adults [68,69]. Accordingly, elevated levels of adiponectin and decreased leptin levels were reported in diabetic men and women after 6-month intervention with a high dose of curcumin (1500 mg/day) [70]. Similar effects on serum levels of leptin were observed in 
males and females with NAFLD treated for 12 weeks with even higher doses of curcumin ( $3000 \mathrm{mg} /$ day) [71]. In conclusion, all the studies discussed show that curcumin supplementation contributes to rebalance pro- and anti-inflammatory factor production significantly increasing the levels of anti-inflammatory adipocytokines, such as adiponectin, and decreasing the pro-inflammatory ones, such as TNF $\alpha$, IL- 6 , IL-1 $\beta$, and MCP-1, counteracting the chronic inflammatory condition in overweight/obese subjects (Table 1).

Table 1. Effects of curcumin on inflammation in obesity: human studies.

\begin{tabular}{|c|c|c|c|c|c|}
\hline Study Design & Subjects & Treatment & Duration & Outcomes & References \\
\hline $\begin{array}{c}\text { Randomized } \\
\text { double-blind, } \\
\text { placebo-controlled }\end{array}$ & $\begin{array}{l}\text { Overweight/obese } \\
\text { with NAFLD } \\
\text { (males and females, } \\
n=84 \text { ) }\end{array}$ & $\begin{array}{l}42 \text { curcumin } \\
(40 \mathrm{mg} / \text { day }) \\
42 \text { placebo }\end{array}$ & 3 months & $\begin{array}{c}\downarrow \text { TNF-alpha and } \\
\text { IL-6 }\end{array}$ & [53] \\
\hline $\begin{array}{c}\text { Randomized, } \\
\text { double-blind, } \\
\text { placebo-controlled }\end{array}$ & $\begin{array}{c}\text { Overweight/obese } \\
\text { with MetS } \\
\text { (males and females, } \\
n=117 \text { ) }\end{array}$ & $\begin{array}{l}59 \text { curcumin }(1 \mathrm{~g} / \text { day }) \\
58 \text { placebo }\end{array}$ & 8 weeks & $\begin{array}{c}\downarrow \mathrm{TNF}-\alpha, \mathrm{IL}-6 \text {, and } \\
\text { MCP-1 }\end{array}$ & [7] \\
\hline $\begin{array}{c}\text { Randomized, } \\
\text { double-blind, } \\
\text { placebo-controlled }\end{array}$ & $\begin{array}{l}\text { Overweight/obese } \\
\text { (adolescent girls, } \\
n=60 \text { ) }\end{array}$ & $\begin{array}{l}30 \text { curcumin } \\
(500 \mathrm{mg} / \text { day }) \\
30 \text { placebo }\end{array}$ & 10 weeks & $\downarrow$ IL-6 & [54] \\
\hline $\begin{array}{l}\text { Randomized, } \\
\text { double blind, } \\
\text { crossover }\end{array}$ & $\begin{array}{c}\text { Obese } \\
\text { (males and females, } \\
n=30 \text { ) }\end{array}$ & $\begin{array}{c}15 \text { curcumin }(1 \mathrm{~g} / \text { day }+ \\
5 \mathrm{mg} \text { bioperine }) \\
15 \text { placebo }\end{array}$ & $\begin{array}{c}4 \text { weeks each } \\
\text { treatment }+ \\
2 \text { weeks wash-out } \\
\text { between the } \\
\text { regimens. }\end{array}$ & $\begin{array}{c}\downarrow \mathrm{IL}-1 \beta \\
\text { no changes IL-6, } \\
\text { and MCP-1 }\end{array}$ & [55] \\
\hline $\begin{array}{c}\text { Randomized, } \\
\text { double-blind, } \\
\text { placebo-controlled }\end{array}$ & $\begin{array}{c}\text { Overweight/obese } \\
\text { with T2D } \\
\text { (males and females, } \\
n=100 \text { ) }\end{array}$ & $\begin{array}{l}50 \text { curcumin } \\
(300 \mathrm{mg} / \text { day }) \\
50 \text { placebo }\end{array}$ & 3 months & $\downarrow$ FFA & [56] \\
\hline $\begin{array}{c}\text { Randomized, } \\
\text { double-blind, } \\
\text { placebo-controlled }\end{array}$ & $\begin{array}{c}\text { T2D } \\
\text { (unspecified gender } \\
n=100)\end{array}$ & $\begin{array}{c}50 \text { curcumin }(1 \mathrm{~g}+ \\
10 \mathrm{mg} \text { piperine/day }) \\
50 \text { placebo }\end{array}$ & 12 weeks & $\begin{array}{l}\downarrow \text { TNF- } \alpha \text { and } \\
\text { Leptin } \\
\uparrow \text { Adiponectin }\end{array}$ & [64] \\
\hline $\begin{array}{c}\text { Randomized, } \\
\text { double-blind, } \\
\text { placebo-controlled }\end{array}$ & $\begin{array}{l}\text { Overweight with } \\
\text { T2D (males and } \\
\text { females, } n=44 \text { ) }\end{array}$ & $\begin{array}{l}21 \text { curcumin } \\
(1500 \mathrm{mg} / \text { day }) \\
23 \text { placebo }\end{array}$ & 10 weeks & $\begin{array}{c}\uparrow \text { Adiponectin } \\
\downarrow \text { weight }\end{array}$ & [66] \\
\hline $\begin{array}{c}\text { Randomized, } \\
\text { double-blind, } \\
\text { placebo-controlled }\end{array}$ & $\begin{array}{c}\text { Obese } \\
\text { (males and females, } \\
29 \text { adults, } 29 \\
\text { children) }\end{array}$ & $\begin{array}{l}15 \text { children curcumin } \\
\text { (500 mg/day) } \\
14 \text { children placebo } \\
15 \text { adults curcumin } \\
\text { (500 mg/day) } \\
14 \text { adults placebo }\end{array}$ & 4 weeks & $\begin{array}{c}\downarrow \text { Leptin } \\
\downarrow \text { Resistin } \\
\uparrow \text { Adiponectin }\end{array}$ & {$[68,69]$} \\
\hline $\begin{array}{c}\text { Randomized, } \\
\text { double-blind, } \\
\text { placebo-controlled }\end{array}$ & $\begin{array}{l}\text { Obese with MetS } \\
\text { (males and females, } \\
\quad n=120 \text { ) }\end{array}$ & $\begin{array}{c}40 \text { curcumin }(1 \mathrm{~g} / \text { day }) \\
40 \text { placebo } \\
40 \text { phospholipidated } \\
\text { curcumin }(1 \mathrm{~g} / \text { day })\end{array}$ & 6 weeks & $\uparrow$ Adiponectin & [65] \\
\hline $\begin{array}{c}\text { Randomized, } \\
\text { double-blind, } \\
\text { placebo-controlled }\end{array}$ & $\begin{array}{l}\text { Overweight T2D } \\
\text { (males and females, } \\
n=210 \text { ) }\end{array}$ & $\begin{array}{l}107 \text { curcumin } \\
(1.5 \mathrm{~g} / \text { day }) \\
103 \text { placebo }\end{array}$ & 6 months & $\begin{array}{c}\downarrow \text { Leptin } \\
\uparrow \text { Adiponectin }\end{array}$ & [70] \\
\hline $\begin{array}{c}\text { Randomized } \\
\text { double-blind, } \\
\text { placebo-controlled }\end{array}$ & $\begin{array}{c}\text { Overweight } \backslash \text { obese } \\
\text { with } \\
\text { NAFLD } \\
\text { (males and females, } \\
\quad n=46 \text { ) }\end{array}$ & $\begin{array}{l}23 \text { curcumin ( } 3 \mathrm{~g} / \text { day }) \\
23 \text { placebo }\end{array}$ & 12 weeks & $\downarrow$ Leptin & [71] \\
\hline
\end{tabular}


Table 1. Cont.

\begin{tabular}{|c|c|c|c|c|c|}
\hline Study Design & Subjects & Treatment & Duration & Outcomes & References \\
\hline $\begin{array}{c}\text { Randomized } \\
\text { double-blind, } \\
\text { placebo-controlled }\end{array}$ & $\begin{array}{c}\text { Obese } \\
(\text { males, } n=22)\end{array}$ & $\begin{array}{l}11 \text { curcumin } \\
\text { (500 mg/day) } \\
11 \text { placebo }\end{array}$ & 12 weeks & $\begin{array}{c}\text { no change } \\
\text { Adiponectin }\end{array}$ & [67] \\
\hline
\end{tabular}

Abbreviations: $\uparrow$ Increases; $\downarrow$ Decreases; IL-6, interleukin-6; IL-1 $\beta$, interleukin-1 $\beta$; MCP-1, monocyte chemoattractant protein-1; TNF $\alpha$, tumor necrosis factor $\alpha$;FF, free fatty acids; T2D, type 2 diabetes; MetS, metabolic syndrome; NAFLD; nonalcoholic fatty liver disease.

\section{Effects of Curcumin on Inflammatory Signaling Pathways}

Most of the potential molecular mechanisms responsible for the health effects of curcumin have been studied in animals and in vitro models using stabilized cell lines or human primary cells. Although the results obtained in this way cannot be completely extrapolated to humans, they allowed to suggest possible mechanisms of curcumin action that could explain the phenotypic effects evidenced by the studies carried out in humans (Figure 1). As regards animal studies, the anti-inflammatory effect of curcumin was first demonstrated in acute and chronic models of inflammation in rats and mice [72]. Specifically, in obese mice, curcumin treatment ( $3 \%$ by weight for 6 weeks) decreases NF- $\mathrm{kB}$ activity in liver tissue, associated with decreased hepatic expression of inflammatory molecules, such as TNF $\alpha$ and MCP-1. Curcumin-treated obese mice also show a decreased macrophage infiltration and an increased expression of forkhead transcription factor (Foxo) 1 and adiponectin into $\mathrm{AT}$, and higher circulating adiponectin levels [72]. In line with these results, an in vivo study performed in male rats, T2D insulin resistant because of high-fat diet (HFD) consumption, demonstrated oral administration of curcumin $(80 \mathrm{mg} / \mathrm{kg}$ body weight) was able to improve insulin sensitivity by attenuating $\mathrm{TNF} \alpha$ serum levels [73]. Moreover, dietary curcumin ( $4 \mathrm{~g} / \mathrm{kg}$ diet added 2 days/week) attenuated the inflammatory response induced by HFD in mice through inhibiting NF-KB expression and JNK signaling pathway in epididymal AT [74]. Interestingly, administration of $0.1 \%$ curcumin associated with white pepper $\left(0.01 \%\right.$ ) (Curcuma- $\mathrm{P}^{\circledR}$ ) significantly down-regulated the proinflammatory cytokines IL- 6 and TNF $\alpha$, but did not modify IL- $1 \beta$ and MCP-1, in the subcutaneous AT of mice after 4 weeks of HFD. This effect was relatively tissue-specific and independent on macrophage infiltration. Indeed, the inflammatory cell infiltration in AT was not modified by Curcuma- $\mathrm{P}^{\circledR}$ supplementation [75]. Another interesting activity of curcumin has been demonstrated on endoplasmic reticulum (ER). The involvement of ER stress (with accumulation of misfolded proteins) in the release of FFA has been observed in several studies [76-78]. Curcumin has been demonstrated to mitigate ER stress in mice fed HFD and in primary adipocytes. Specifically, short-term HFD feeding (10 days) increased ER stress in mouse AT by increasing the expression of phospho-inositol-requiring kinase 1(p-IRE1) and phospho-eukaryotic Initiation Factor 2 (p-eIF2), two important indicators of ER stress. Oral administration of curcumin $(50 \mathrm{mg} / \mathrm{kg}$ ) counteracted the activation of IRE1 and eIF2 by reducing the phosphorylation, and consequently inhibiting the ER stress in vivo. Similarly, curcumin $(0.1,1,10 \mu \mathrm{M})$ treatment inhibited IRE1 and eIF2 activation in mouse AT treated with $100 \mu \mathrm{M}$ of palmitate (inductor of ER stress). Furthermore, curcumin administration reduced glycerol and FFA released from AT of HFD-fed mice blocking cAMP/PKA signaling via regulation of AMP-activated protein kinase (AMPK) [79], as well as significantly decreased plasma FFA levels in HF-induced obese rats [80]. Several in vitro models have been used to collect more detailed information about the potential molecular mechanisms of action through which curcumin exerts its effects. Curcumin has been shown to inhibit the activation of the pro-inflammatory NF- $\mathrm{kB}$ signaling pathway in several cell types, including human adipocytes and macrophages [48]. In adipocytes treated with TNF $\alpha$ to induce inflammatory processes, the contemporary treatment with $20 \mu \mathrm{M}$ curcumin suppressed the degradation of I $\mathrm{K} B \alpha$, the NF- $\mathrm{k} B$ inhibitor, reducing, consequently, NF- $\mathrm{k} B$ translocation to the nucleus and significantly inhibiting the expression of TNF $\alpha$, IL-1 $\beta$, IL- 6 and COX2 genes and IL-6 secretion [81]. In the same type of cells, curcumin also exerts a protective effect on hypoxia in a dose-dependent manner $(5,10$, and $20 \mu \mathrm{M})$ reducing the secretion of 
the inflammatory cytokines and protecting mitochondrial functions [82]. Besides a direct effect on adipocytes, curcumin has been shown to exert anti-inflammatory effects by counteracting the increased recruitment of macrophages in AT from obese mice $[72,83]$. Several studies have evidenced that curcumin treatment reduces macrophage invasion of AT in mouse models of obesity [62,72]. It has been shown that the cross-talk between adipocytes and macrophages in AT triggers and increases inflammatory responses in obesity including the increased production of MCP-1 and other inflammatory cytokines [84,85]. Curcumin treatment $(0.1-10 \mu \mathrm{M})$ of Raw 264.7 macrophages incubated with the culture medium of mesenteric AT taken from obese mice, potentially able to induce an inflammatory response, significantly inhibited the production of $\mathrm{TNF} \alpha, \mathrm{MCP}-1$, and nitric oxide, as well as the migration capacity of the macrophages with respect to the cells not treated with curcumin. Furthermore, $10 \mu \mathrm{M}$ curcumin treatment significantly inhibited MCP-1 release from 3T3-L1 adipocytes [86]. Studies carried out in different cell systems strongly suggest that the anti-inflammatory activity of curcumin occurs by modulating NLRP3 inflammasome. In THP-1 macrophages treated with phorbol 12-myristate 13-acetate (PMA), an activator of NLRP3 inflammasome, curcumin $(6.25,12.5$, and $25 \mu \mathrm{M})$ reduced NLRP3 inflammasome level, the activation of caspase- 1 and the secretion of IL- $1 \beta$ in a dose-dependent manner, most likely down-regulating TLR4/NF-KB signal transduction pathway that is involved in NLRP3 inflammasome activation [87]. In mouse bone marrow-derived macrophages (BMDM) treated with nigericin, another NLRP3 inflammasome activator, the pre-treatment with curcumin $(30-50 \mu \mathrm{M})$ inhibited caspase- 1 cleavage and IL-1 $\beta$ secretion. The same results were observed in human macrophages. Specifically, differentiated THP-1 cells pretreated with curcumin showed reduced caspase- 1 activation and IL-1 $\beta$ secretion after treatment with LPS and nigericin. The inhibition of NLRP3 activation by curcumin appears to be due to the suppression of $\mathrm{K}^{+}$efflux [88].

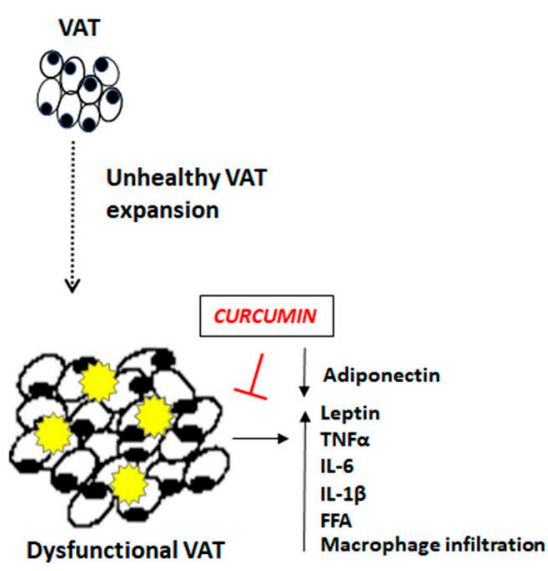

MACROPHAGE

INHIBITION
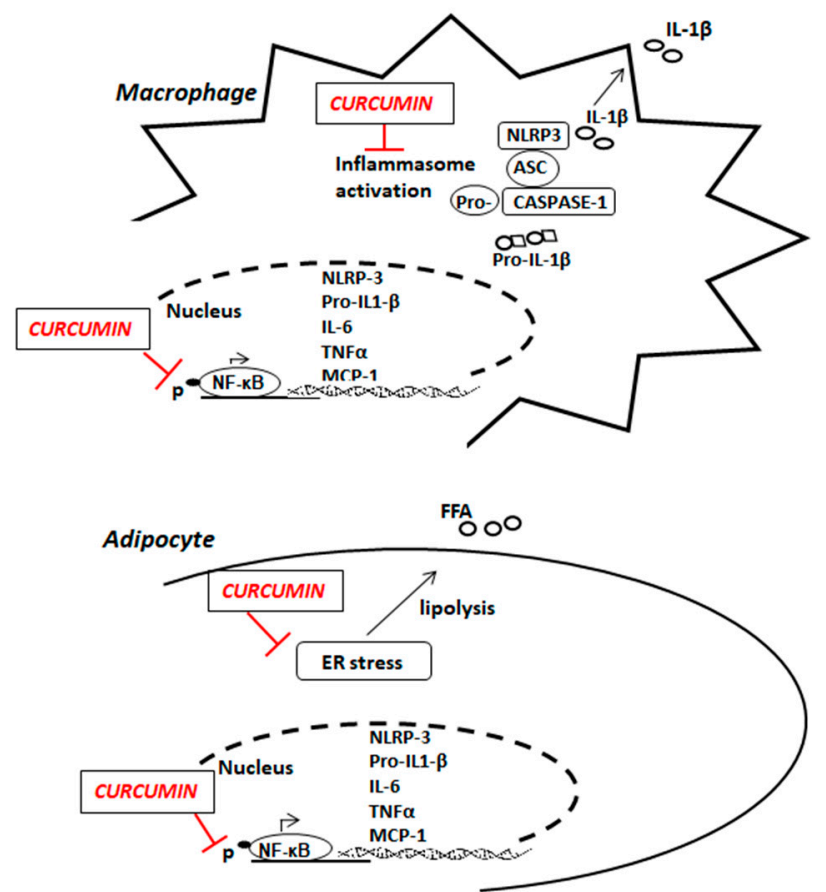

Figure 1. Potential anti-inflammatory mechanisms of curcumin in obesity. VAT: visceral adipose tissue; FFA: free fatty acids; TNF $\alpha$ : tumor necrosis factor $\alpha$; IL-6: interleukin 6; IL-1 $\beta$ : interleukin $\beta$; ER: endoplasmic reticulum; NF- $\mathrm{kB}$ : Nuclear transcriptor factor kappa B; MCP-1: Monocyte chemoattractant protein-1; NLRP-3: nod-like receptor pyrin domain-containing 3.

In conclusion, a growing body of experimental data supports the hypothesis that the beneficial effects of curcumin on obesity-related pathologies may be related to the 
suppression of IL-6, TNF $\alpha$, IL-1 $\beta$, and MCP-1 expression from adipocytes, the inhibition of macrophage recruitment in AT, and the inhibition of the inflammatory activity of the NLRP3 inflammasome [89] (Table 2).

Table 2. Effects of curcumin on inflammation in obesity: in vivo and in vitro studies.

\begin{tabular}{|c|c|c|c|c|}
\hline Animal Model & Diet & Duration & Outcome & References \\
\hline $\begin{array}{l}\text { Male C57BL/ } 6 \text { mice } \\
\text { Wild-type and ob/ob }\end{array}$ & $\begin{array}{l}\text { Standard diet ( } 4 \% \text { fat }) \pm \\
\text { curcumin } 3 \% \text { by weight } \\
\text { HFD (35\% fat) } \pm \text { curcumin } \\
3 \% \text { by weight } \\
\text { ( } n=5 / \text { group })\end{array}$ & 6-weeks & $\begin{array}{c}\text { in adipose tissue } \\
\uparrow \text { Foxo1 and adiponectin } \\
\text { expression } \\
\downarrow \text { infiltration of macrophages } \\
\uparrow \text { circulating Adiponectin } \\
\text { levels } \\
\downarrow \text { MCP-1. } \\
\downarrow \mathrm{TNF} \alpha, \mathrm{MCP}-1 \text { expression, } \\
\text { and NF- } \mathrm{B} \text { activity in liver }\end{array}$ & [72] \\
\hline Male Sprague Dawley rats & $\begin{array}{c}\text { Standard diet (control) } \\
\text { HFD } \\
\text { HFD + curcumin } \\
(80 \mathrm{mg} / \mathrm{kg} / \text { day }) \\
(n=11 / \text { group })\end{array}$ & $\begin{array}{l}60 \text { days } \\
75 \text { days }\end{array}$ & $\begin{array}{c}\downarrow \text { FFA and TNF } \alpha \text { serum } \\
\text { levels in all group compared } \\
\text { to non-treated HFD groups }\end{array}$ & [73] \\
\hline Male C57BL/6J mice & $\begin{array}{c}\text { Low-fat diet ( } 10 \% \text { Kcal from } \\
\text { fat) } \\
\text { HFD ( } 45 \% \text { Kcal from fat) } \\
\text { HFD + curcumin ( } 4 \mathrm{~g} / \mathrm{kg} \\
\text { diet) } \\
\text { ( } n=12 / \text { group) }\end{array}$ & 28 weeks & $\begin{array}{c}\text { in adipose tissue } \\
\downarrow \text { macrophage infiltration } \\
\downarrow N F-\kappa B \text { expression and JNK } \\
\text { signaling pathway activation }\end{array}$ & [74] \\
\hline Male C57BL/6J mice & $\begin{array}{c}\text { Standard Diet (control) } \\
\text { HFD } \\
\text { HFD + Curcuma- } \mathrm{P}^{\circledR}(0.1 \% \\
\text { curcumin }+0.01 \% \text { white } \\
\text { pepper }) \\
(n=8 / \text { group })\end{array}$ & 4 weeks & $\begin{array}{c}\downarrow \mathrm{IL}-6 \text { and } \mathrm{TNF} \alpha, \text { no changes } \\
\text { in MCP1, IL-1 } \beta, \text { CD68, and } \\
\text { F4/80 in adipose tissue }\end{array}$ & [75] \\
\hline Male C57BL/ 6 mice & $\begin{array}{c}\text { HFD } \\
\mathrm{HFD}+\underset{(n=6 / \text { group })}{\text { curcumin }(50 \mathrm{mg} / \mathrm{kg})}\end{array}$ & 10 days & $\begin{array}{l}\downarrow \text { ER stress in adipose tissue } \\
\downarrow \text { FFA release from adipose } \\
\text { tissue }\end{array}$ & [79] \\
\hline Male Wistar rats & $\begin{array}{c}\text { Standard diet (control) } \\
\text { HFD } \\
\text { HFD + curcuminoid }(30,60, \\
90 \mathrm{mg} \backslash \mathrm{Kg} \text { body weigth } \backslash \text { day }) \\
(n=12 \text { /group) }\end{array}$ & 12 weeks & $\downarrow$ FFA plasma levels & [80] \\
\hline
\end{tabular}

Raw 264.7 macrophages treated with conditioned

Standard diet ( $4 \%$ fat) \pm curcumin $3 \%$ by weight $3 \%$ by weight $(n=5 /$ group $)$

\section{Cell type} medium by mesenteric adipose tissue

0.1-1-10 $\mu \mathrm{M}$ curcumin $10 \mu \mathrm{M}$ curcumin

3T3-L1 adipocytes

$$
\text { levels }
$$$$
\downarrow \mathrm{MCP}-1
$$

$\downarrow \mathrm{TNF} \alpha, \mathrm{MCP}-1$ expression and NF- $\mathrm{KB}$ activity in liver to non-treated HFD groups

in adipose tissue $\downarrow$ macrophage infiltration KB expression and JNK signaling pathway activation

$\downarrow$ IL- 6 and TNF $\alpha$, no changes MCP1, IL-1 $\beta$, CD68, and $\mathrm{F} 4 / 80$ in adipose tissue

$\downarrow$ ER stress in adipose tissu adipose

$\downarrow$ TNF $\alpha$ and MCP- 1 release $\downarrow \mathrm{MCP}-1$ release

$\downarrow N F-\kappa B$ activation.

$\downarrow$ TNF $\alpha$, IL-1 $\beta$, IL-6, expression

$\downarrow$ IL-6 secretion with TNF- $\alpha$

2-20 $\mu \mathrm{M}$ curcumin

$62 \mathrm{~h}$ 
Table 2. Cont

\begin{tabular}{|c|c|c|c|c|}
\hline Animal Model & Diet & Duration & Outcome & References \\
\hline $\begin{array}{l}\text { THP-1 macrophages } \\
\text { treated with PMA }\end{array}$ & $6.25,12.5,25 \mu \mathrm{M}$ curcumin & $24 \mathrm{~h}$ & $\begin{array}{c}\downarrow \text { NLRP3 inflammasome } \\
\text { expression, } \\
\text { caspase- } 1 \text { activation, IL-1ß } \\
\text { secretion, } \\
\text { TLR4 expression, and NF- } \kappa B \\
\text { activation }\end{array}$ & [87] \\
\hline $\begin{array}{c}\text { Mouse, bone } \\
\text { marrow-derived } \\
\text { macrophages (BMDM) } \\
\text { treated with nigericin (10 } \\
\text { mM) } \\
\text { THP-1 cells treated with } \\
\text { LPS }\end{array}$ & $\begin{array}{l}\text { 30-50 } \mu \mathrm{M} \text { curcumin } \\
30-50 \mu \mathrm{M} \text { curcumin }\end{array}$ & $1 \mathrm{~h}$ & $\begin{array}{c}\downarrow \text { caspase- } 1 \text { cleavage } \\
\downarrow \text { IL- } 1 \beta \text { secretion } \\
\downarrow \text { caspase- } 1 \text { activation } \\
\downarrow \text { IL- } 1 \beta \text { secretion }\end{array}$ & [88] \\
\hline
\end{tabular}

Abbreviations: $\uparrow$ Increases; $\downarrow$ Decreases; IL-6, interleukin-6; IL-1 $\beta$, interleukin-1 $\beta$; MCP-1, monocyte chemoattractant protein-1; TNF $\alpha$, tumor necrosis factor $\alpha$; FFA, free fatty acids; HFD, high-fat diet; ER, endoplasmic reticulum; LPS, lipopolysaccharides; PMA, phorbol 12-myristate 13-acetate; Foxo1, forkhead transcription factor 1; NF- $\kappa$ B, nuclear transcriptor factor kappa B; JNK, jun N-terminal kinase; TLR4, toll-like receptor 4; NLRP3, nod-like receptor pyrin domain-containing 3.

\section{Conclusions}

The inflammation present in AT is involved in the development of various obesityrelated pathologies. The studies reported in this review clearly show that curcumin supplementation significantly decreases inflammatory cytokine production and increases adiponectin level in plasma of obese and overweight subjects. Furthermore, curcumin can regulate several molecular targets including transcription factors (NF-kB, NLP3), signaling pathways and other complex regulatory systems in AT resulting in the suppression/attenuation of the chronic low-grade inflammation. However, since curcumin is widely used as a supplement around the world because of its health promoting properties, further studies, both in vitro to better define the mechanisms of action, and in humans by controlled gender-based clinical trials to evaluate the real effectiveness, are mandatory. It should be reached, thus, that ultimate evidence on curcumin effects and highlighted possible differences in the response to curcumin treatment between women and men, allowing the definition of personalized advice about curcumin consumption.

Author Contributions: R.V., B.S., and R.M. provided substantial contributions to the conception of the work, as well as manuscript writing; C.G., A.S. contributed to the final discussion and revision of the manuscript. All authors have read and agreed to the published version of the manuscript.

Funding: This review received no external funding.

Institutional Review Board Statement: Not applicable.

Informed Consent Statement: Not applicable.

Data Availability Statement: Data sharing is not applicable to this article.

Conflicts of Interest: The authors declare no conflict of interest.

\section{References}

1. Jin, T.R. Curcumin and dietary polyphenol research: Beyond drug discovery. Acta Pharmacol. Sin. 2018, 39, 779-786. [CrossRef]

2. Kocaadam, B.; Sanlier, N. Curcumin, an active component of turmeric (Curcuma longa), and its effects on health. Crit. Rev. Food Sci. Nutr. 2017, 57, 2889-2895. [CrossRef] [PubMed]

3. Gupta, S.C.; Patchva, S.; Aggarwal, B.B. Therapeutic roles of curcumin: Lessons learned from clinical trials. AAPS J. 2013, 15, 195-218. [CrossRef] [PubMed]

4. Bradford, P.G. Curcumin and obesity. BioFactors 2013, 39, 78-87. [CrossRef]

5. Aggarwal, B.B.; Harikumar, K.B. Potential therapeutic effects of curcumin, the anti-inflammatory agent, against neurodegenerative, cardiovascular, pulmonary, metabolic, autoimmune and neoplastic diseases. Int. J. Biochem. Cell Biol. 2009, 41, 40-59. [CrossRef] 
6. Sohaei, S.; Amani, R.; Tarrahi, M.J.; Ghasemi-Tehrani, H. The effects of curcumin supplementation on glycemic status, lipid profile and hs-CRP levels in overweight/obese women with polycystic ovary syndrome: A randomized, double-blind, placebo-controlled clinical trial. Complementary Ther. Med. 2019, 47, 102201. [CrossRef] [PubMed]

7. Panahi, Y.; Hosseini, M.S.; Khalili, N.; Naimi, E.; Simental-Mendia, L.E.; Majeed, M.; Sahebkar, A. Effects of curcumin on serum cytokine concentrations in subjects with metabolic syndrome: A post-hoc analysis of a randomized controlled trial. Biomed. Pharmacother. 2016, 82, 578-582. [CrossRef]

8. Chooi, Y.C.; Ding, C.; Magkos, F. The epidemiology of obesity. Metab. Clin. Exp. 2019, 92, 6-10. [CrossRef]

9. Thyagarajan, B.; Foster, M.T. Beiging of white adipose tissue as a therapeutic strategy for weight loss in humans. Horm. Mol. Biol. Clin. Investig. 2017, 31, 1-13. [CrossRef]

10. Emanuela, F.; Grazia, M.; Marco de, R.; Maria Paola, L.; Giorgio, F.; Marco, B. Inflammation as a link between obesity and metabolic syndrome. J. Nutr. Metab. 2012, 2012, 476380. [CrossRef]

11. Schwartz, B.; Yehuda-Shnaidman, E. Putative role of adipose tissue in growth and metabolism of colon cancer cells. Front. Oncol. 2014, 4, 164. [CrossRef]

12. Galic, S.; Oakhill, J.S.; Steinberg, G.R. Adipose tissue as an endocrine organ. Mol. Cell. Endocrinol. 2010, 316, 129-139. [CrossRef]

13. Esser, N.; Legrand-Poels, S.; Piette, J.; Scheen, A.J.; Paquot, N. Inflammation as a link between obesity, metabolic syndrome and type 2 diabetes. Diabetes Res. Clin. Pract. 2014, 105, 141-150. [CrossRef]

14. Wellen, K.E.; Hotamisligil, G.S. Obesity-induced inflammatory changes in adipose tissue. J. Clin. Investig. 2003, 112, 1785-1788. [CrossRef]

15. Lee, B.C.; Lee, J. Cellular and molecular players in adipose tissue inflammation in the development of obesity-induced insulin resistance. Biochim. Biophys. Acta 2014, 1842, 446-462. [CrossRef] [PubMed]

16. Romacho, T.; Elsen, M.; Rohrborn, D.; Eckel, J. Adipose tissue and its role in organ crosstalk. Acta Physiol. 2014, $210,733-753$. [CrossRef]

17. Stern, J.H.; Rutkowski, J.M.; Scherer, P.E. Adiponectin, leptin, and fatty acids in the maintenance of metabolic homeostasis through adipose tissue crosstalk. Cell Metab. 2016, 23, 770-784. [CrossRef]

18. Kershaw, E.E.; Flier, J.S. Adipose tissue as an endocrine organ. J. Clin. Endocrinol. Metab. 2004, 89, 2548-2556. [CrossRef]

19. Weisberg, S.P.; McCann, D.; Desai, M.; Rosenbaum, M.; Leibel, R.L.; Ferrante, A.W., Jr. Obesity is associated with macrophage accumulation in adipose tissue. J. Clin. Investig. 2003, 112, 1796-1808. [CrossRef] [PubMed]

20. Castoldi, A.; Naffah de Souza, C.; Camara, N.O.; Moraes-Vieira, P.M. The macrophage switch in obesity development. Front. Immunol. 2015, 6, 637. [CrossRef]

21. Boulenouar, S.; Michelet, X.; Duquette, D.; Alvarez, D.; Hogan, A.E.; Dold, C.; O'Connor, D.; Stutte, S.; Tavakkoli, A.; Winters, D.; et al. Adipose type one innate lymphoid cells regulate macrophage homeostasis through targeted cytotoxicity. Immunity 2017, 46, 273-286. [CrossRef]

22. Suganami, T.; Tanimoto-Koyama, K.; Nishida, J.; Itoh, M.; Yuan, X.; Mizuarai, S.; Kotani, H.; Yamaoka, S.; Miyake, K.; Aoe, S.; et al. Role of the Toll-like receptor 4/NF-kappaB pathway in saturated fatty acid-induced inflammatory changes in the interaction between adipocytes and macrophages. Arterioscler. Thromb. Vasc. Biol. 2007, 27, 84-91. [CrossRef]

23. Castellano-Castillo, D.; Morcillo, S.; Clemente-Postigo, M.; Crujeiras, A.B.; Fernandez-Garcia, J.C.; Torres, E.; Tinahones, F.J.; Macias-Gonzalez, M. Adipose tissue inflammation and VDR expression and methylation in colorectal cancer. Clin. Epigenetics 2018, 10, 60. [CrossRef]

24. Griffin, C.; Eter, L.; Lanzetta, N.; Abrishami, S.; Varghese, M.; McKernan, K.; Muir, L.; Lane, J.; Lumeng, C.N.; Singer, K. TLR4, TRIF, and MyD88 are essential for myelopoiesis and CD11c(+) adipose tissue macrophage production in obese mice. J. Biol. Chem. 2018, 293, 8775-8786. [CrossRef] [PubMed]

25. Luna-Vital, D.; Luzardo-Ocampo, I.; Cuellar-Nunez, M.L.; Loarca-Pina, G.; Gonzalez de Mejia, E. Maize extract rich in ferulic acid and anthocyanins prevents high-fat-induced obesity in mice by modulating SIRT1, AMPK and IL-6 associated metabolic and inflammatory pathways. J. Nutr. Biochem. 2020, 79, 108343. [CrossRef]

26. Chawla, A.; Nguyen, K.D.; Goh, Y.P. Macrophage-mediated inflammation in metabolic disease. Nature reviews. Immunology 2011, 11, 738-749. [CrossRef]

27. Reilly, S.M.; Saltiel, A.R. Adapting to obesity with adipose tissue inflammation. Nat. Rev. Endocrinol. 2017, 13, 633-643. [CrossRef] [PubMed]

28. Yamashita, A.S.; Belchior, T.; Lira, F.S.; Bishop, N.C.; Wessner, B.; Rosa, J.C.; Festuccia, W.T. Regulation of metabolic diseaseassociated inflammation by nutrient sensors. Mediat. Inflamm. 2018, 2018, 8261432. [CrossRef]

29. Hocking, S.; Samocha-Bonet, D.; Milner, K.L.; Greenfield, J.R.; Chisholm, D.J. Adiposity and insulin resistance in humans: The role of the different tissue and cellular lipid depots. Endocr. Rev. 2013, 34, 463-500. [CrossRef] [PubMed]

30. Shi, H.; Kokoeva, M.V.; Inouye, K.; Tzameli, I.; Yin, H.; Flier, J.S. TLR4 links innate immunity and fatty acid-induced insulin resistance. J. Clin. Investig. 2006, 116, 3015-3025. [CrossRef]

31. Shoelson, S.E.; Lee, J.; Yuan, M. Inflammation and the IKK beta/I kappa B/NF-kappa B axis in obesity- and diet-induced insulin resistance. International journal of obesity and related metabolic disorders. J. Int. Assoc. Study Obes. 2003, 27, S49-S52. [CrossRef]

32. Muruzabal, F.J.; Fruhbeck, G.; Gomez-Ambrosi, J.; Archanco, M.; Burrell, M.A. Immunocytochemical detection of leptin in non-mammalian vertebrate stomach. Gen. Comp. Endocrinol. 2002, 128, 149-152. [CrossRef] 
33. Ajuwon, K.M.; Spurlock, M.E. Adiponectin inhibits LPS-induced NF-kappaB activation and IL-6 production and increases PPARgamma2 expression in adipocytes. Am. J. Physiol. Regul. Integr. Comp. Physiol. 2005, 288, R1220-R1225. [CrossRef] [PubMed]

34. Ouchi, N.; Kihara, S.; Arita, Y.; Okamoto, Y.; Maeda, K.; Kuriyama, H.; Hotta, K.; Nishida, M.; Takahashi, M.; Muraguchi, M.; et al. Adiponectin, an adipocyte-derived plasma protein, inhibits endothelial NF-kappaB signaling through a cAMP-dependent pathway. Circulation 2000, 102, 1296-1301. [CrossRef]

35. Schmidt, F.M.; Weschenfelder, J.; Sander, C.; Minkwitz, J.; Thormann, J.; Chittka, T.; Mergl, R.; Kirkby, K.C.; Fasshauer, M.; Stumvoll, M.; et al. Inflammatory cytokines in general and central obesity and modulating effects of physical activity. PLoS ONE 2015, 10, e0121971. [CrossRef] [PubMed]

36. Ghadge, A.A.; Khaire, A.A.; Kuvalekar, A.A. Adiponectin: A potential therapeutic target for metabolic syndrome. Cytokine Growth Factor Rev. 2018, 39, 151-158. [CrossRef]

37. Horng, T.; Hotamisligil, G.S. Linking the inflammasome to obesity-related disease. Nat. Med. 2011, 17, 164-165. [CrossRef] [PubMed]

38. Vandanmagsar, B.; Youm, Y.H.; Ravussin, A.; Galgani, J.E.; Stadler, K.; Mynatt, R.L.; Ravussin, E.; Stephens, J.M.; Dixit, V.D. The NLRP3 inflammasome instigates obesity-induced inflammation and insulin resistance. Nat. Med. 2011, 17, 179-188. [CrossRef] [PubMed]

39. Strowig, T.; Henao-Mejia, J.; Elinav, E.; Flavell, R. Inflammasomes in health and disease. Nature 2012, 481, 278-286. [CrossRef]

40. Finucane, O.M.; Sugrue, J.; Rubio-Araiz, A.; Guillot-Sestier, M.V.; Lynch, M.A. The NLRP3 inflammasome modulates glycolysis by increasing PFKFB3 in an IL-1beta-dependent manner in macrophages. Sci. Rep. 2019, 9, 4034. [CrossRef]

41. Gianfrancesco, M.A.; Dehairs, J.; L'Homme, L.; Herinckx, G.; Esser, N.; Jansen, O.; Habraken, Y.; Lassence, C.; Swinnen, J.V.; Rider, M.H.; et al. Saturated fatty acids induce NLRP3 activation in human macrophages through K(+) efflux resulting from phospholipid saturation and Na, K-ATPase disruption. Biochim. Biophys. Acta Mol. Cell Biol. Lipids 2019, 1864, 1017-1030. [CrossRef]

42. Esser, N.; L'Homme, L.; De Roover, A.; Kohnen, L.; Scheen, A.J.; Moutschen, M.; Piette, J.; Legrand-Poels, S.; Paquot, N. Obesity phenotype is related to NLRP3 inflammasome activity and immunological profile of visceral adipose tissue. Diabetologia 2013, 56, 2487-2497. [CrossRef] [PubMed]

43. Keane, K.N.; Cruzat, V.F.; Carlessi, R.; de Bittencourt, P.I., Jr.; Newsholme, P. Molecular events linking oxidative stress and inflammation to Insulin resistance and beta-cell dysfunction. Oxid. Med. Cell. Longev. 2015, 2015, 181643. [CrossRef] [PubMed]

44. Xin, Y.; Wang, Y.; Chi, J.; Zhu, X.; Zhao, H.; Zhao, S.; Wang, Y. Elevated free fatty acid level is associated with insulin-resistant state in nondiabetic Chinese people. Diabetes Metab. Syndr. Obes. Targets Ther. 2019, 12, 139-147. [CrossRef] [PubMed]

45. Saberi, M.; Woods, N.B.; de Luca, C.; Schenk, S.; Lu, J.C.; Bandyopadhyay, G.; Verma, I.M.; Olefsky, J.M. Hematopoietic cellspecific deletion of toll-like receptor 4 ameliorates hepatic and adipose tissue insulin resistance in high-fat-fed mice. Cell Metab. 2009, 10, 419-429. [CrossRef]

46. Nguyen, M.T.; Favelyukis, S.; Nguyen, A.K.; Reichart, D.; Scott, P.A.; Jenn, A.; Liu-Bryan, R.; Glass, C.K.; Neels, J.G.; Olefsky, J.M. A subpopulation of macrophages infiltrates hypertrophic adipose tissue and is activated by free fatty acids via Toll-like receptors 2 and 4 and JNK-dependent pathways. J. Biol. Chem. 2007, 282, 35279-35292. [CrossRef]

47. McKernan, K.; Varghese, M.; Patel, R.; Singer, K. Role of TLR4 in the induction of inflammatory changes in adipocytes and macrophages. Adipocyte 2020, 9, 212-222. [CrossRef]

48. Shehzad, A.; Ha, T.; Subhan, F.; Lee, Y.S. New mechanisms and the anti-inflammatory role of curcumin in obesity and obesityrelated metabolic diseases. Eur. J. Nutr. 2011, 50, 151-161. [CrossRef]

49. Shimizu, K.; Funamoto, M.; Sunagawa, Y.; Shimizu, S.; Katanasaka, Y.; Miyazaki, Y.; Wada, H.; Hasegawa, K.; Morimoto, T. Anti-inflammatory action of curcumin and its use in the treatment of lifestyle-related diseases. Eur. Cardiol. 2019, 14, 117-122. [CrossRef] [PubMed]

50. Di Pierro, F.; Bressan, A.; Ranaldi, D.; Rapacioli, G.; Giacomelli, L.; Bertuccioli, A. Potential role of bioavailable curcumin in weight loss and omental adipose tissue decrease: Preliminary data of a randomized, controlled trial in overweight people with metabolic syndrome. Preliminary study. Eur. Rev. Med. Pharmacol. Sci. 2015, 19, 4195-4202.

51. Akbari, M.; Lankarani, K.B.; Tabrizi, R.; Ghayour-Mobarhan, M.; Peymani, P.; Ferns, G.; Ghaderi, A.; Asemi, Z. The effects of curcumin on weight loss among patients with metabolic syndrome and related disorders: A systematic review and meta-analysis of randomized controlled trials. Front. Pharmacol. 2019, 10, 649. [CrossRef]

52. Srinivasan, K. Black pepper and its pungent principle-piperine: A review of diverse physiological effects. Crit. Rev. Food Sci. Nutr. 2007, 47, 735-748. [CrossRef]

53. Jazayeri-Tehrani, S.A.; Rezayat, S.M.; Mansouri, S.; Qorbani, M.; Alavian, S.M.; Daneshi-Maskooni, M.; Hosseinzadeh-Attar, M.J. Nano-curcumin improves glucose indices, lipids, inflammation, and Nesfatin in overweight and obese patients with non-alcoholic fatty liver disease (NAFLD): A double-blind randomized placebo-controlled clinical trial. Nutr. Metab. 2019, 16, 8. [CrossRef]

54. Saraf-Bank, S.; Ahmadi, A.; Paknahad, Z.; Maracy, M.; Nourian, M. Effects of curcumin supplementation on markers of inflammation and oxidative stress among healthy overweight and obese girl adolescents: A randomized placebo-controlled clinical trial. Phytother. Res. PTR 2019, 33, 2015-2022. [CrossRef]

55. Ganjali, S.; Sahebkar, A.; Mahdipour, E.; Jamialahmadi, K.; Torabi, S.; Akhlaghi, S.; Ferns, G.; Parizadeh, S.M.; Ghayour-Mobarhan, M. Investigation of the effects of curcumin on serum cytokines in obese individuals: A randomized controlled trial. Sci. World J. 2014, 2014, 898361. [CrossRef] 
56. Na, L.X.; Li, Y.; Pan, H.Z.; Zhou, X.L.; Sun, D.J.; Meng, M.; Li, X.X.; Sun, C.H. Curcuminoids exert glucose-lowering effect in type 2 diabetes by decreasing serum free fatty acids: A double-blind, placebo-controlled trial. Mol. Nutr. Food Res. 2013, 57, 1569-1577. [CrossRef] [PubMed]

57. Arner, P.; Ryden, M. Fatty acids, obesity and insulin resistance. Obes. Facts 2015, 8, 147-155. [CrossRef]

58. Boden, G. Obesity and free fatty acids. Endocrinol. Metab. Clin. N. Am. 2008, 37, 635-646. [CrossRef] [PubMed]

59. Glass, C.K.; Olefsky, J.M. Inflammation and lipid signaling in the etiology of insulin resistance. Cell Metab. 2012, 15, 635-645. [CrossRef] [PubMed]

60. Fruhbeck, G.; Catalan, V.; Rodriguez, A.; Ramirez, B.; Becerril, S.; Salvador, J.; Colina, I.; Gomez-Ambrosi, J. Adiponectin-leptin ratio is a functional biomarker of adipose tissue inflammation. Nutrients 2019, 11, 454. [CrossRef]

61. Liu, W.; Zhou, X.; Li, Y.; Zhang, S.; Cai, X.; Zhang, R.; Gong, S.; Han, X.; Ji, L. Serum leptin, resistin, and adiponectin levels in obese and non-obese patients with newly diagnosed type 2 diabetes mellitus: A population-based study. Medicine 2020, 99, e19052. [CrossRef]

62. Zhao, Y.; Chen, B.; Shen, J.; Wan, L.; Zhu, Y.; Yi, T.; Xiao, Z. The beneficial effects of quercetin, curcumin, and resveratrol in obesity. Oxidative Med. Cell. Longev. 2017, 2017, 1459497. [CrossRef]

63. Simental-Mendia, L.E.; Cicero, A.F.G.; Atkin, S.L.; Majeed, M.; Sahebkar, A. A systematic review and meta-analysis of the effect of curcuminoids on adiponectin levels. Obes. Res. Clin. Pract. 2019, 13, 340-344. [CrossRef] [PubMed]

64. Panahi, Y.; Khalili, N.; Sahebi, E.; Namazi, S.; Atkin, S.L.; Majeed, M.; Sahebkar, A. Curcuminoids plus piperine modulate adipokines in type 2 diabetes mellitus. Curr. Clin. Pharmacol. 2017, 12, 253-258. [CrossRef] [PubMed]

65. Salahshooh, M.M.; Parizadeh, S.M.R.; Pasdar, A.; Karimian, M.S.; Safarian, H.; Javandoost, A.; Gordon, A.; Mobarhan, M.G.; Sahebkar, A. The effect of curcumin (Curcuma longa L.) on circulating levels of adiponectin in patients with metabolic syndrome. Comp. Clin. Pathol. 2017, 26, 17-23. [CrossRef]

66. Adibian, M.; Hodaei, H.; Nikpayam, O.; Sohrab, G.; Hekmatdoost, A.; Hedayati, M. The effects of curcumin supplementation on high-sensitivity C-reactive protein, serum adiponectin, and lipid profile in patients with type 2 diabetes: A randomized, double-blind, placebo-controlled trial. Phytother. Res. PTR 2019, 33, 1374-1383. [CrossRef] [PubMed]

67. Campbell, M.S.; Ouyang, A.; Krishnakumar, I.M.; Charnigo, R.J.; Westgate, P.M.; Fleenor, B.S. Influence of enhanced bioavailable curcumin on obesity-associated cardiovascular disease risk factors and arterial function: A double-blinded, randomized, controlled trial. Nutrition 2019, 62, 135-139. [CrossRef]

68. Ismail, N.A.; Abd El Dayem, S.M.; Salama, E.; Ragab, S.; Abd El Baky, A.N.; Ezzat, W.M. Impact of Curcumin Intake on GlucoInsulin Homeostasis, Leptin and Adiponectin in Obese Subjects. Res. J. Pharm. Biol. Chem. 2016, 7, 1891-1897.

69. Ismail, N.A.; Ragab, S.; El-Baky, A.N.E.A.; Hamed, M.; Ibrahim, A.A. Effect of oral curcumin administration on insulin resistance, serum resistin and fetuin-A in obese children: Randomized placebo-controlled study. Res. J. Pharm. Biol. Chem. Sci. 2014, 5, 887-896.

70. Chuengsamarn, S.; Rattanamongkolgul, S.; Phonrat, B.; Tungtrongchitr, R.; Jirawatnotai, S. Reduction of atherogenic risk in patients with type 2 diabetes by curcuminoid extract: A randomized controlled trial. J. Nutr. Biochem. 2014, 25, 144-150. [CrossRef]

71. Navekar, R.; Rafraf, M.; Ghaffari, A.; Asghari-Jafarabadi, M.; Khoshbaten, M. Turmeric supplementation improves serum glucose indices and leptin levels in patients with nonalcoholic fatty liver diseases. J. Am. Coll. Nutr. 2017, 36, 261-267. [CrossRef] [PubMed]

72. Weisberg, S.P.; Leibel, R.; Tortoriello, D.V. Dietary curcumin significantly improves obesity-associated inflammation and diabetes in mouse models of diabesity. Endocrinology 2008, 149, 3549-3558. [CrossRef]

73. El-Moselhy, M.A.; Taye, A.; Sharkawi, S.S.; El-Sisi, S.F.; Ahmed, A.F. The antihyperglycemic effect of curcumin in high fat diet fed rats. Role of TNF-alpha and free fatty acids. Food Chem. Toxicol. 2011, 49, 1129-1140. [CrossRef]

74. Shao, W.; Yu, Z.; Chiang, Y.; Yang, Y.; Chai, T.; Foltz, W.; Lu, H.; Fantus, I.G.; Jin, T. Curcumin prevents high fat diet induced insulin resistance and obesity via attenuating lipogenesis in liver and inflammatory pathway in adipocytes. PLoS ONE 2012, 7, e28784. [CrossRef]

75. Neyrinck, A.M.; Alligier, M.; Memvanga, P.B.; Nevraumont, E.; Larondelle, Y.; Preat, V.; Cani, P.D.; Delzenne, N.M. Curcuma longa extract associated with white pepper lessens high fat diet-induced inflammation in subcutaneous adipose tissue. PLoS ONE 2013, 8, e81252. [CrossRef]

76. Arruda, A.P.; Pers, B.M.; Parlakgul, G.; Guney, E.; Inouye, K.; Hotamisligil, G.S. Chronic enrichment of hepatic endoplasmic reticulum-mitochondria contact leads to mitochondrial dysfunction in obesity. Nat. Med. 2014, 20, 1427-1435. [CrossRef] [PubMed]

77. Deng, J.; Liu, S.; Zou, L.; Xu, C.; Geng, B.; Xu, G. Lipolysis response to endoplasmic reticulum stress in adipose cells. J. Chem. 2012, 287, 6240-6249. [CrossRef] [PubMed]

78. Carmen, G.Y.; Victor, S.M. Signaling mechanisms regulating lipolysis. Cell. Signal. 2006, 18, 401-408. [CrossRef]

79. Wang, L.; Zhang, B.; Huang, F.; Liu, B.; Xie, Y. Curcumin inhibits lipolysis via suppression of ER stress in adipose tissue and prevents hepatic insulin resistance. J. Lipid Res. 2016, 57, 1243-1255. [CrossRef]

80. Pongchaidecha, A.; Lailerd, N.; Boonprasert, W.; Chattipakorn, N. Effects of curcuminoid supplement on cardiac autonomic status in high-fat-induced obese rats. Nutrition 2009, 25, 870-878. [CrossRef] [PubMed]

81. Gonzales, A.M.; Orlando, R.A. Curcumin and resveratrol inhibit nuclear factor-kappaB-mediated cytokine expression in adipocytes. Nutr. Metab. 2008, 5, 17. [CrossRef] 
82. Priyanka, A.; Anusree, S.S.; Nisha, V.M.; Raghu, K.G. Curcumin improves hypoxia induced dysfunctions in 3T3-L1 adipocytes by protecting mitochondria and down regulating inflammation. BioFactors 2014, 40, 513-523. [CrossRef]

83. Meydani, M.; Hasan, S.T. Dietary polyphenols and obesity. Nutrients 2010, 2, 737-751. [CrossRef] [PubMed]

84. Bruun, J.M.; Lihn, A.S.; Pedersen, S.B.; Richelsen, B. Monocyte chemoattractant protein-1 release is higher in visceral than subcutaneous human adipose tissue (AT): Implication of macrophages resident in the AT. J. Clin. Endocrinol. Metab. 2005, 90, 2282-2289. [CrossRef]

85. Fain, J.N.; Madan, A.K. Regulation of monocyte chemoattractant protein 1 (MCP-1) release by explants of human visceral adipose tissue. Int. J. Obes. 2005, 29, 1299-1307. [CrossRef] [PubMed]

86. Woo, H.M.; Kang, J.H.; Kawada, T.; Yoo, H.; Sung, M.K.; Yu, R. Active spice-derived components can inhibit inflammatory responses of adipose tissue in obesity by suppressing inflammatory actions of macrophages and release of monocyte chemoattractant protein-1 from adipocytes. Life Sci. 2007, 80, 926-931. [CrossRef]

87. Kong, F.; Ye, B.; Cao, J.; Cai, X.; Lin, L.; Huang, S.; Huang, W.; Huang, Z. Curcumin represses NLRP3 inflammasome activation via TLR4/MyD88/NF-kappaB and P2X7R signaling in PMA-induced macrophages. Front. Pharmacol. 2016, 7, 369. [CrossRef] [PubMed]

88. Yin, H.; Guo, Q.; Li, X.; Tang, T.; Li, C.; Wang, H.; Sun, Y.; Feng, Q.; Ma, C.; Gao, C.; et al. Curcumin suppresses IL-1beta Secretion and prevents inflammation through inhibition of the NLRP3 inflammasome. J. Immunol. 2018, 200, 2835-2846. [CrossRef]

89. Hasanzadeh, S.; Read, M.I.; Bland, A.R.; Majeed, M.; Jamialahmadi, T.; Sahebkar, A. Curcumin: An inflammasome silencer. Pharmacol. Res. 2020, 159, 104921. [CrossRef] [PubMed] 